\title{
手動超音波併用乳癌検診の 50歳未満受診者に対する有効性の検証
}

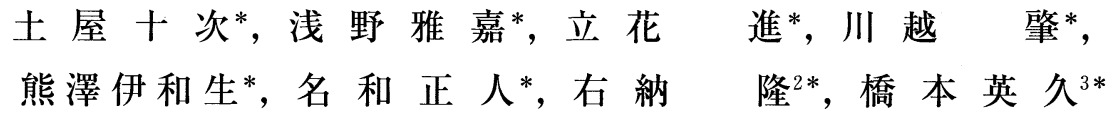

15年間における手動超音波併用乳癌検診（以下，US 併用検診）で検出した乳癌症例 82 例について受診時年齢を 50 歳未満と50歳以上に分けて集検精度, 診断能, 有自覚症状率を 比較した。結果, 50歳未満では50歳以上に比して要精検率, 有自覚症状率が有意に高く陽 性予知度が有意に低いものの, 乳癌発見率, 感度, 特異度はほぼ同率であり50歳以上と同 様に有用な US 併用検診が可能である事が判明した。

組織型の検討では50歳未満の非浸潤癌症例比率が50歳以上に比して有意に多いことが判 明した。US 併用検診では若年受診群において浸潤癌化する以前に乳癌を早期発見するこ とができることを示唆している。

15 年間を 5 年毎の 3 期に分け腫瘤徍を検討したところ，このUS 併用検診の経年的腫瘤 径縮小効果が示唆された。即ち, 微小腫瘤径乳癌が多くなった結果, 非触知乳癌症例が集 検例の $26.6 \%$ 占めるうえにその $72.3 \%$ が浸潤癌症例であったことが判明した。これを更 に年齢別に見ると，50歳未満の群ではその乳腺の硬さから50歳以上の群に比して非触知乳 癌症例比率が多くなって $30.2 \%$ 占め, その $69.2 \%$ 浸潤癌症例であった。視触診検診の みの検診ではこれらは見落とし例となり, 増加しつつある50歳代の乳癌死亡率を更に増悪 させることになるので，これを抑制するために50歳未満の若年受診群に対して安全で有効 な US 併用検診を早急に導入することを提言する。

\section{(1)乳癌検診 (2)超音波検査 (3)検診精度 (4) 非浸潤性乳癌 (5)非触知乳癌}

\section{は じめに}

厚生労働省が推奨する乳房撮影併用検診にお いて従来どおりの視触診検診のみの対応で放置 されている50歳未満の若年受診者に対して, 手 動超音波併用乳癌検診 (以下, US 併用検診) を導入することの有用性を検証する。

\footnotetext{
* \%501-0696 岐阜県揖斐郡揖斐川町三輪 2547-4 揖斐総合病院外科

$2 *$ 同臨床病理部

$3 *$ 同放射線科

(受付：2003年 2 月 28日）
}

\section{対象および検診方法}

1986年 4 月から 2001 年 3 月までの 15 年間に 69,924名に対して行ったUS 併用検診において 検出された集検例 82 例を対象として, 受診時年 齢を50歳未満と50歳以上の群に分けておのおの で検診成績, 検診精度, 診断能の比較を行っ た。更に, 組織型, $\mathrm{T}$ 分類, $\mathrm{n}$ 因子, 腫瘤径, 腫瘤自覚の有無などから検討を加えることによ り50歳未満の若年受診者に対する US 併用検診 の有用性を検証した。

この US 併用検診とは医師 1 名が出張し, 仰 
臥位の受診者に視触診を行い，同時に医師自身 が探触子を手動走查しつつ real timeに Whole Breast Scanning して低エコー領域の有無や豹 紋・乳腺構築の乱れなどを検索するものであ り，受診者 1 名につきほぼ 3 分間の検診時間を 要した。検診に用いた超音波診断装置は7.5 $\mathrm{MHz}$ ，電子スキャナー型リアルタイム方式の 診断装置である。

\section{結果}

1 ）US 併用検診の検診精度と診断能の評価

US 併用検診全例に対する検診精度は乳癌発 見率 $0.12 \%$, 要精検率 $6.0 \%$, 感度 $93.2 \%$, 特 異度 $94.2 \%$, 陽性予知度 $2.0 \%$, 有自覚症状率
$32.5 \%$ あった（表 1 -a）。これを50歳以上 （表 1 - b) と50歳未満（表 1 - c) に分けて比 較すると乳癌発見率, 感度, 特異度, 有自覚症 状率はほぼ同率であるが，50歳未満の群では50 歳以上の群に比して要精検率が有意に高く（P $<0.001$, (O) , 陽性予知度が有意に低 $<（ \mathrm{P}<$ 0.005, 氕), 更に, 有自覚症状率が有意に高い $(\mathrm{P}<0.001$ ， 丸）ことが判明した。

2 ) US 併用検診における非浸潤癌と非触知乳 癌

組織型を検討したところ15年間に15例， 18.3\%の非浸潤癌症例が検出されていた（表 2 )。これを年齢別に見ると，50歳未満の群で は43例中の 12 例， $27.9 \%$ が非浸潤癌症例である

表 1. 集検成績と集検精度の比較

表 1 - a. 検診全体

\begin{tabular}{c}
$\frac{\text { 総受診者数 }}{\text { 要精検者数 }(\text { 率 })}$ \\
\hline 乳癌発見数 $($ 率 $)$ \\
\hline 中間期乳癌数 \\
\hline 感度 \\
\hline 特異度 \\
\hline 陽性予知度 \\
\hline 有自覚症状率
\end{tabular}

\begin{tabular}{|c|}
\hline 69,924 名 \\
\hline 4,173 名 $(6.0 \%)$ \\
\hline 82 名 $(0.12 \%)$ \\
\hline 6 名 \\
\hline $93.2 \%$ \\
\hline $94.2 \%$ \\
\hline $2.0 \%$ \\
\hline $32.8 \%$ \\
\hline
\end{tabular}

表 $1-b .50$ 歳以上

\begin{tabular}{|c|}
\hline 31,792 名 \\
\hline 1,386 名 $(4.4 \%)$ \\
\hline 39 名 $(0.12 \%)$ \\
\hline 3 名 \\
\hline $92.9 \%$ \\
\hline $95.8 \%$ \\
\hline $2.8 \%$ 㘧 \\
\hline $27.0 \% \star$ \\
\hline
\end{tabular}

表 1 - c. 50歳未満

\begin{tabular}{|c|}
\hline 38,132 名 \\
\hline 2,787 名 $(7.3 \%)$ \\
\hline 43 名 $(0.11 \%)$ \\
\hline 3 名 \\
\hline $93.5 \%$ \\
\hline $92.9 \%$ \\
\hline $1.5 \%$ 坊 \\
\hline $38.5 \% \star$ \\
\hline
\end{tabular}

(0) $\cdots \mathrm{P}<0.001, \quad$ 放 $\cdots \mathrm{P}<0.005$,

‥P $<0.001$ （1986年 4 月～2001年 3 月）

表 2. US 併用検診における非浸潤癌と非触知乳癌

\begin{tabular}{|c|c|c|c|c|c|c|c|}
\hline $\mathrm{T}$ 分類 & 非浸潤癌 & 乳頭腺管癌 & 充実腺管癌 & 硬 癌 & 粘液癌 & 髄様癌 & 計 \\
\hline \multirow{2}{*}{ 非触知乳癌 } & 6 & 5 & 7 & \multirow{2}{*}{$\underbrace{4}_{\%)}$} & & & \multirow{2}{*}{$22(26.8 \%)$} \\
\hline & 非浸潤癌 (27. & $3 \%)$ & - 浸潤癌 $(72$. & & & & \\
\hline $\mathrm{T} 1 \mathrm{a}$ & 9 & 8 & 12 & 14 & 1 & 2 & 46 \\
\hline $\mathrm{T} 1 \mathrm{~b}$ & & 2 & & & & & 2 \\
\hline $\mathrm{T} 2 \mathrm{a}$ & & 5 & 1 & 4 & & & 10 \\
\hline $\mathrm{T} 4 \mathrm{a}$ & & 1 & & & & & 1 \\
\hline $\mathrm{T} 4 \mathrm{~b}$ & & & & 1 & & & 1 \\
\hline 計 & $15(18.3 \%)$ & 21 & 20 & 23 & 1 & 2 & 82 \\
\hline
\end{tabular}


表 3. 年齢別に見た非浸潤癌と非触知乳癌

\begin{tabular}{|c|c|c|c|c|c|}
\hline & \multicolumn{2}{|c|}{ 50歳未満 } & \multicolumn{2}{|c|}{ 50歳以上 } & \multirow{2}{*}{ 計 } \\
\hline & 非浸潤 & 浸潤 & 非浸潤 & 浸潤 & \\
\hline \multirow{3}{*}{ 非触知乳癌 } & 4 & 9 & 2 & 7 & \multirow{3}{*}{$\begin{array}{c}22 \\
\text { [非触知 } 26.8 \% \text { ] }\end{array}$} \\
\hline & \multicolumn{2}{|c|}{13 [非触知 $30.2 \%$ ] } & \multicolumn{2}{|c|}{9 [非触知 $23.1 \%$ ] } & \\
\hline & \multicolumn{2}{|c|}{$30.8 \% \longrightarrow 69.2 \%$} & \multicolumn{2}{|c|}{$22.2 \% \longleftrightarrow 77.8 \%$} & \\
\hline \multirow{5}{*}{ 触知乳癌 } & 8 & $22\left(4^{*}\right)$ & 1 & $29\left(7^{*}\right)$ & \multirow{3}{*}{60} \\
\hline & & & & & \\
\hline & \multicolumn{2}{|c|}{$26.7 \% \longleftrightarrow 73.3 \%$} & \multicolumn{2}{|c|}{$3.3 \% \longleftrightarrow 96.7 \%$} & \\
\hline & $12^{25}$ & 31 & 3 立 & 36 & \multirow{2}{*}{82} \\
\hline & \multicolumn{2}{|c|}{43} & \multicolumn{2}{|c|}{39} & \\
\hline
\end{tabular}

*リンパ節転移陽性症例数， [非触知 $\%$ ] $\cdots$ 非触知乳癌率， 放 $\mathrm{P}<0.05$

のに対して，50歳以上の群では非浸潤癌症例が 39 例中 3 例， $7.7 \%$ みで有意に少なくなって いた（P<0.05，表 3 の方）。US 併用検診は50 歳未満の非浸潤癌が乳管壁を穿破し浸潤癌化す る前に早期発見し得ることを示唆している。

一方, 検診医も精検担当医も腫瘤を触知でき ない非触知乳癌は発見乳癌 82 例のうちの 22 例, $26.8 \%$ 占めており, その内訳は $27.3 \%$ 非浸

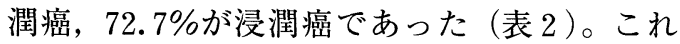
は視触診のみの検診では全発見乳癌の 4 分の 1 が見落とされ，その 7 割が浸潤癌であったこと を示唆している。これを年齢別に見ると非触知 乳癌は50歳未満の群では $30.2 \%$ 占め 50 歳以上 の群の $23.1 \%$ よ多く, そのうちの $69.2 \%$ が浸 潤癌症例であった（表 3 )。50歳未満の若年受 診群では50歳以上の群に比してその乳腺組織が 硬いために視触診検診のみでは見落とし例が多 くなることと, その 7 割が浸潤癌症例であった ことを示しており，これらを検出するUS 併用 検診の有用性が示唆された。

3 ) US 併用検診における腫瘤径と $\mathrm{n}$ 分類

検診発見乳癌の腫瘤径と $\mathrm{n}$ 分類の関係を見 ると, 腫瘤径が小さくなるに従いリンパ節転移 陽性率も低下する傾向を示し, 腫瘤径 $20 \mathrm{~mm}$
以下の群ではリンパ節転移陽性率が $20 \mathrm{~mm}$ 以 上の群に比して有意に低くなっていた（P< 0.01 , 表 4 の○)。しかし, 腫瘤径 $11 \mathrm{~mm}$ から $20 \mathrm{~mm}$ の群で $10 \%, 5 \mathrm{~mm}$ から $10 \mathrm{~mm}$ の微小 腫瘤径乳癌群でも $8.6 \%$ がリンパ節転移陽性症 例であったことは注目に值する。又，リンパ節 転移陽性例は全てが触知・浸潤癌症例のなかに 認められる（表 3 の）ことから, 非触知・非 浸潤癌のうちに早期発見することの重要性が示 唆された。

4）US 併用検診における経年的腫瘤径縮小効 果

検診期間の 15 年間を 5 年毎の前・中・後の 3 期に分けて見ると, 後期において有意に腫瘤径 が小さくなっており, 平均腫瘤径は $12 \mathrm{~mm} に$ まで縮小していた（P<0.05，表 5 の※)。US 併用検診では逐年受診者の増加に伴い微小腫瘤 径乳癌がより多く検出されるようになり経年的 腫瘤径縮小効果がもたらされたものと考えられ る。

各期ごとにリンパ節転移陰性群（以下， $\mathrm{n}$ 群）と陽性群（以下, $\mathrm{n}+$ 群）に分け, 更に $\mathrm{n}$ 一群においては検診受診時の腫瘤自覚群と非自 覚群に分けて腫瘤径を比較した（表 5 )。n一- 
群は $\mathrm{n}+$ 群に比して腫瘤径が有意に小さく, な かでも腫瘤非自覚群は中期から後期にかけて有

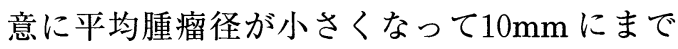
縮小していた $(\mathrm{P}<0.01$, 表 5 の○)。これは US 併用検診を継続するに従い逐年受診者が増 え, この中から腫瘤非自覚の微小腫瘤径乳癌症
例が多く検出されるようになったためと考えて いる。

5 ）年齢別に見た腫瘤自覚状況と腫瘤径変遷 原発巣実測值の平均腫瘤径を年齢別に見ると 50 歳以上の自覚群が有意に $(\mathrm{P}<0.05)$ 大き く, 全体としては50歳未満の群の方が50歳以上

表 4. 検診発見乳癌の腫瘤径と $\mathrm{n}$ 分類

\begin{tabular}{|c|c|c|c|c|c|c|c|}
\hline 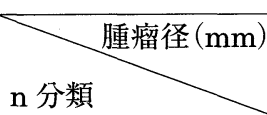 & $\sim 5$ & $5 \sim 10$ & $11 \sim 20$ & $21 \sim 30$ & $31 \sim 40$ & $41 \sim 50$ & 計 \\
\hline no & 3 & 32 & 27 & 6 & 2 & & 70 \\
\hline $\mathrm{n} 1 \alpha$ & & 3 & 2 & 1 & & 1 & 7 \\
\hline $\mathrm{n} 1 \beta$ & & & 1 & 1 & 2 & & 4 \\
\hline $\mathrm{n} 2$ & & & & 1 & & & 1 \\
\hline \multirow[t]{2}{*}{ 計 } & $\begin{array}{c}3 \\
(0 \%)\end{array}$ & $\begin{array}{c}35 \\
(8.6 \%)\end{array}$ & $\begin{array}{c}30 \\
(10 \%)\end{array}$ & $\begin{array}{c}9 \\
(33.3 \%)\end{array}$ & $\begin{array}{c}4 \\
(50 \%)\end{array}$ & $\begin{array}{c}1 \\
(100 \%)\end{array}$ & \multirow{2}{*}{$\begin{array}{c}82 \\
(\mathrm{n}+\text { 率 } \cdots 14.6 \%)\end{array}$} \\
\hline & \multicolumn{3}{|c|}{$68\left(\mathrm{n}+\bar{s}^{\prime} \cdots 8.8 \%\right)$} & \multicolumn{3}{|c|}{ 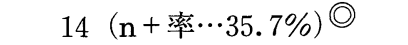 } & \\
\hline
\end{tabular}

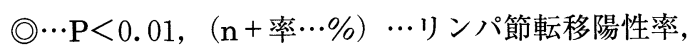
…リンパ節転移陽性症例

表 5.リンパ節転移・腫瘤自覚の有無と経年的腫瘤径縮小効果

\begin{tabular}{|c|c|c|c|c|}
\hline & & 前期 & 中期 & 後期 \\
\hline & 年度 & 1986年～’91年 & ’92年〜'96年 & '97年～2001年 \\
\hline & $\begin{array}{l}\text { 重瘤径（mm） } \\
=\text { 症例数） }\end{array}$ & $\begin{array}{c}18.2 \pm 10.7 \\
\quad(\mathrm{n}=19)\end{array}$ & $\begin{array}{c}14.6 \pm 6.7 \\
(\mathrm{n}=29)\end{array}$ & $\begin{array}{c}12.1 \pm 5.0 \% \\
(\mathrm{n}=34)\end{array}$ \\
\hline$\stackrel{\text { ? }}{*}$ & 腫瘤非自覚群 & $15.2 \pm 8.0$ & $14.4 \pm 6.0$ & $0^{10.4 \pm 4.3}$ \\
\hline 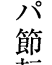 & $(\mathrm{n}=54)$ & & $\Delta(n=19)$ & 1 (c) $(n=23)$ \\
\hline $\begin{array}{l}\text { 移 } \\
\text { 陰 } \\
\text { 性 } \\
\text { 群 }\end{array}$ & $\begin{array}{l}\text { 腫瘤自覚群 } \\
\quad(\mathrm{n}=18)\end{array}$ & $\begin{array}{l}21.5 \pm 13.3 \\
(\mathrm{n}=6)\end{array}$ & $\begin{array}{l}11.6 \pm 4.9 \\
4_{(\mathrm{n}=7)}\end{array}$ & $\begin{array}{c}14.4 \pm 5.3 \\
(\mathrm{n}=5)\end{array}$ \\
\hline リン & $\begin{array}{l}\text { 節転移陽性群 } \\
(\mathrm{n}=10)\end{array}$ & $\begin{array}{c}35 \\
(n=1)\end{array}$ & $\begin{array}{c}24.3 \pm 6.0 \\
(\mathrm{n}=3)\end{array}$ & $\begin{array}{c}15.8 \pm 5.2 \\
(\mathrm{n}=6)\end{array}$ \\
\hline
\end{tabular}

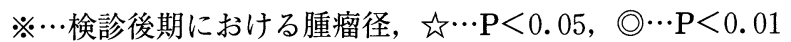


表 6. 50歳未満と50歳以上における自覚・非自覚群の腫瘤径 $(\mathrm{mm})$ 変遷

\begin{tabular}{|c|c|c|c|c|c|c|}
\hline 年齢別 腫瘤 & $\begin{array}{r}\text { 年代別 } \\
\text { 自覚 }\end{array}$ & $\begin{array}{l}\text { 前期 }(\mathrm{n}=19) \\
(1986 \sim 90 \text { 年 })\end{array}$ & $\begin{array}{l}\text { 中期 }(\mathrm{n}=29) \\
\text { ('91〜'95年) }\end{array}$ & $\begin{array}{l}\text { 後期 (n=34) } \\
(' 96 \sim 2000 \text { 年) }\end{array}$ & & \\
\hline \multirow{2}{*}{$\begin{array}{c}50 \text { 歳未満 } \\
(\mathrm{n}=43)\end{array}$} & 非自覚群 & $\begin{array}{c}15.5 \pm 8.8 \\
(\mathrm{n}=6)\end{array}$ & $\begin{array}{c}14.2 \pm 7.2 \\
(\mathrm{n}=10) \\
\end{array}$ & $\begin{array}{l}9.6 \pm 4.0 \\
(\mathrm{n}=11)\end{array}$ & $\begin{array}{c}12.6 \pm 6.8 \\
(\mathrm{n}=27)\end{array}$ & \multirow{2}{*}{$13.7 \pm 7.4$} \\
\hline & 自覚群 & $\begin{array}{c}19.3 \pm 14.9 \\
(\mathrm{n}=4)\end{array}$ & $\begin{array}{c}12.2 \pm 5.7 \\
(\mathrm{n}=5)\end{array}$ & $\begin{array}{c}15.9 \pm 4.5 \\
(\mathrm{n}=7)\end{array}$ & $\begin{array}{c}15.6 \pm 8.3 \\
(\mathrm{n}=16)\end{array}$ & \\
\hline \multirow{2}{*}{$\begin{array}{c}\text { 50歳以上 } \\
(\mathrm{n}=39)\end{array}$} & 非自覚群 & $\begin{array}{c}13.2 \pm 8.3 \\
(\mathrm{n}=6)\end{array}$ & $\begin{array}{c}14.5 \pm 5.0 \\
(\mathrm{n}=10)\end{array}$ & $\begin{array}{c}11.0 \pm 4.5 \\
(\mathrm{n}=13)\end{array}$ & \multirow{2}{*}{\begin{tabular}{c}
$\begin{array}{c}12.8 \pm 5.7 \\
(\mathrm{n}=29) \\
21.0 \pm 10.1 \\
(\mathrm{n}=10)\end{array}$ \\
\hdashline
\end{tabular}} & \multirow{2}{*}{$15.0 \pm 7.9$} \\
\hline & 自覚群 & $\begin{array}{c}29.0 \pm 10.4 \\
(\mathrm{n}=3)\end{array}$ & $\begin{array}{c}18.8 \pm 10.4 \\
(n=4)\end{array}$ & $\begin{array}{c}16.0 \pm 6.2 \\
(\mathrm{n}=3)\end{array}$ & & \\
\hline
\end{tabular}

の群より小さい傾向にあった（表 6 ）。

経年的に 5 年毎で見ると 50 歳未満の若年受診 者において，なかでもその非自覚群の平均腫瘤 径が後期において $9.6 \mathrm{~mm}$ となり腫瘤自覚群の 腫瘤径に比して有意に縮小していた $(\mathrm{P}<0.01$, 表 6 の○)。硬い乳腺が多い50歳未満の若年受 診群において, 視触診のみの検診ではこの腫瘤 径が有意に小さな非自覚群の中に見落とし例が 多く出ることが危惧される。

\section{考察}

視触診のみの乳癌検診では10年累積生存率が

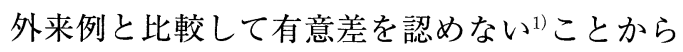
厚生労働省は 2000 年 4 月にマンモグラフィ併用 乳癌検診 (以下, MMG 併用検診) を推奨する 旨を通達している。ただし，この適応は50歳以 上の受診者に限定した隔年検診とし，50歳未満 の若年受診者に対しては従来どおりの視触診検 診のみの対応としている。この50歳未満の若年 受診者に対して MMG 併用を推奖しなかった 理由は50歳未満の若年受診者の $8 \%$ から $15 \%$ を 占める高密度乳房例 ${ }^{2,3)} に よ り$ 検診精度が劣化 することと, 放射線被曝に対するリスク ${ }^{4,5}$ が 拭い去れないことによる。これに対して我々 は, US 併用検診が50歳未満の若年受診者に対 しても50歳以上の受診者と同様な検診精度と診 断能をもって行い得ることを示すとともに，放
射線被曝リスクもなく安全で逐年検診が可能で あることから経年的腫瘤径縮小効果がもたらさ れることを指摘した。

厚生労働省が50歳未満の若年受診群に対して MMG 併用を推奨せず視触診検診のみの対応と した背景には，欧米の randomized control trial (以下, RCT) の結果が根拠としてあるよ うである。即ち, 欧米の MMG 併用検診の RCT の結果, 50歳以上では有効であると言えるが, 50歳未満の若年受診者に対しては未だ MMG 併用検診の有効性評価は定まってはおらず6), 21か国のうち13か国が50歳以上に対象を限定し 50歳未満には MMG 併用検診を行っていない のが現状である ${ }^{5)}$ この検診方式は50歳以上, なかでも60歳代・70歳代の乳癌罹患率が最も高 い欧米においては当を得た方式であるが，40歳 代に既に乳癌罹患率の peakが来る本邦（図 $1)^{7)}$ においては従来どおりの効率が低い視触 診検診のみの対応で50歳未満を放置する方式で は見落とし例が多くなる点で難があると言わざ るを得ない。

一方，本邦における年齢別乳癌死亡率を 1955 年以後 10 年ごとに経年的に見ると，50歳の死亡 率が暫時増大して peakを形成し, 将来的に見 ても50歳の死亡率が増加してゆく傾向にある (図 2$)^{8)}$ 。この50歳の死亡率の上昇は40歳代 に発症した乳癌が放置され増悪する事が関与し 


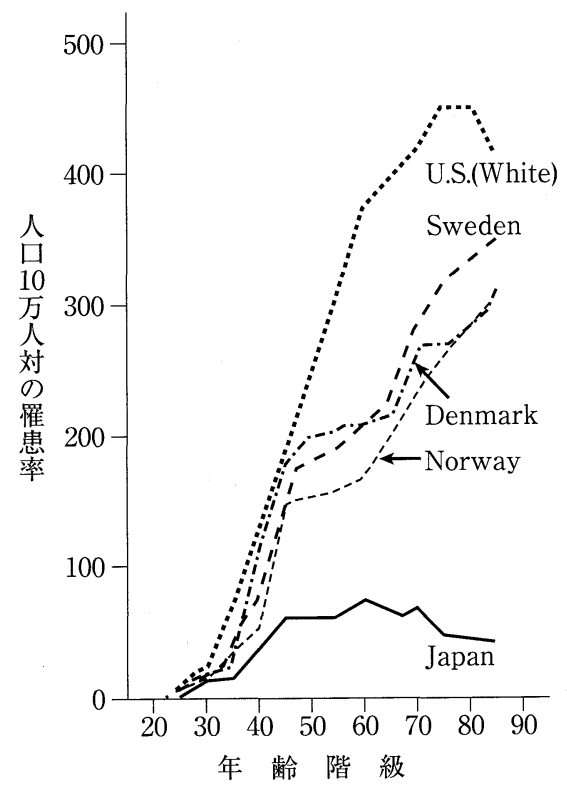

図 1.わが国と欧米諸国との年齢別乳癌 罹患率の比較

ており，本邦において急増する50歳代の死亡率 を抑制するには40歳代にこそ視触診検診を凌駕 する検診方式を導入する事が急務である。その 対策として我々は，既に医療機関に可成り広く 普及している安価な超音波検査機器を視触診検 診に上乗せしてWhole Breast Scanningする US 併用検診を，50歳未満の若年受診群に早急 に導入することを提唱する。

15年間の視触診のみの検診を集計した鯉淵 $ら^{9)}$ は, 腫瘤径の縮小傾向は見られるものの後 期における平均腫瘤径 $20 \mathrm{~mm}$ が視触診検診の 発見限界であると報告しているのに対して，視 触診に手動超音波検査を併用した我々の US 併 用検診では後期において発見乳癌の平均腫瘤径 が12mmにまで縮小し (表 5 の※)，なかでも， 50歳未満の非自覚群では後期において平均腫瘤 径が9.6mm にまで縮小していた（表 6 の○)。 これはUS 併用検診の逐年受診者の増加に伴 い，そのなかから微小腫瘤径乳癌が多数検出さ れ経年的腫瘤径縮小効果を示したものと考えて いる。このように腫瘤径が縮小する50歳未満の 若年受診群においては検診発見乳癌の $30 \%$ US 所見のみで検出された非触知乳癌症例で

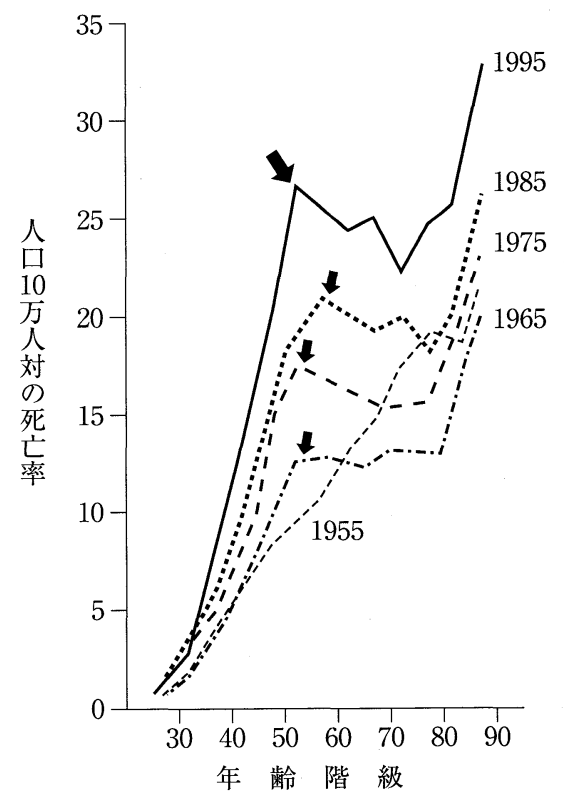

図 2.わが国における年齢別乳癌死亡率 の経年的変遷

あったが，視触診のみの検診ではこれらは全て 見落とされることになる。更に，これらのうち の70\%が浸潤癌症例であったことは，触れるこ とができないほど小さな乳癌だから大丈夫と 言って看過できないことを示唆すると共に，50 歳未満の若年受診群で見落とされたこれらの微 小腫瘤径の浸潤癌が50歳代の乳癌死亡率を押し 上げる要因になることを危惧させる事例であ る。又, $5 \mathrm{~mm}$ から $10 \mathrm{~mm}$ の微小腫瘤径乳癌 群でも $8.6 \%$ がリンパ節転移陽性症例であり

（表 4)，更にリンパ節転移陽性例は全例が浸 潤・触知症例であった（表 3 の*）ことから見 ても矢張りUS 併用検診で早期に検出すること が重要である。

US 併用検診は放射線被曝リスクがないので 若年受診者にも安全に逐年検診が可能であるう えに，若年者に多い高密度乳腺にも影響される 事なく微小腫瘤径乳癌の早期発見を可能にする 優れた方式であることを強調したい。

我々は昭和 58 年から, 医師が椅子に座って患 者を待つのではなく, 病院を一歩踏み出して早 期乳癌発見に努めるべくUS 併用検診を開始し た。当初から, 前房水型プローブ, $7.5 \mathrm{Mhz}$ の 
ポータブルとは言うものの一抱えもある大きな US 機器を車に積んで出張検診を行い年間500 名ほどから始まり，現在では年間7,000名ほど の受診者を 5 名の外科医で US 併用検診してい る。受診者は500円ほどの負担金で，あとは町 村の補助金2,500円ほどでまかなってきたが， 経済全般の冷込みに伴い検診に対する地方交付 金の縛りが無くなるなど何かと懸念材料が多く なってきた。既に受益者負担の発想から大都会 では施設検診でそれ相応の検診料を払って安心 を買う風潮にあり，又，津々浦々に浸透する motorization も拍車をかけて我々の出張検診 の存在自体が危ぶまれる昨今であるが，地域一 体となった啓蒙活動の重要性や検診カバー率を 考える時, 又, 農村・山間僻地で我々の検診を 待つ人々を思う時，まだまだこの出張 US 併用 検診を継続してゆく意義は大いにあると確信し ている。

\section{結語}

1）15年間における手動超音波併用乳癌検診 （以下, US 併用検診）は検診精度, 診断能 から見て50歳未満の若年受診者に対しても50 歳以上と同様に安全で有効な検診が可能であ る。

$2 ） 50$ 歳未満の若年受診者に対して視触診検診 のみの対応で放置していると，その $30 \%$ 非 触知乳癌症例として見落とされるうえに，そ のうちの $70 \%$ が浸潤癌であるため, 増大しつ つある50歳代の乳癌死亡率をさらに押し上げ
る結果になることが危惧される。50歳未満の 若年受診群に早急にUS 併用検診を導入する ことを提唱する。

\section{文献}

1）厚生省公衆衛生局編．昭和54年第 4 次悪性新生物 実態調查報告. 日本対癌協会, 1980, p. 68 .

2 ）近藤博之, 山口哲央, 黒田怜子, 他. スクリーン マンモグラフィの課題一40歳代のマンモグラフィ 撮影の工夫一. 日乳癌検診学会誌 $1988 ; 7: 81$ -86 .

3) 東野英利子, 植野 映, 角田博子, 他. 超音波を 用いた乳癌検診の有用性と問題点. 日乳癌検診学 会誌 $2000 ； 9: 151-153$.

4) Land CE, Boice JD, Shore RE, et al. Breast cancer risk from low dose exposure to ionizing radiation : results of parallel analysis of three exposed population in women. J Natl Cancer Inst. 1980 ; $65: 353-376$.

5 ）大内憲明, 飯沼 武, 森本忠興, 他. 49歳以下の マンモグラフィ検診による死亡リスク減少効果一 欧米における臨床試験のレビュー，日乳癌検診学 会誌 $1998 ； 7: 13-23$.

6 ）平成12年度厚生労働省がん検診の適正化に関する 調查研究事業報告. 新たながん検診手法の有効性 の評価. 日本公衆衛生協会, 2001, pp. 247--275.

7) Parkin DM, Muir CS, Whelan SL, et al. Cancer Incidence in Five Continents. vol IV. IARC Sci Publ No. 120. Lyon : IARC, 1992.

8 ) Kuroishi T, Hirose K, and Tajima K. "Cancer Mortality in Japan", Gann Monograph on Cancer Research (1999).

9 ）鯉淵幸生, 飯野佑一, 横江隆夫, 他. 群馬県の乳 癌集団検診受診者の年代別特徴. 日乳癌検診学会 誌 $1998 ； 7: 143-147$. 


\title{
Hand-Scanning Ultrasound Mass Screening for Breast Cancer in Women Aged Under 50
}

\author{
Juji TSUCHIYA*, Masayoshi ASANO*, Susumu TACHIBANA*, \\ Hajime KAWAGOE* , Hajime KAWAGOE* , Iwao KUMAZAWA*, \\ Masato NAWA*, Takashi $\mathrm{UNO}^{2 *}$ and Hidehisa HASHIMOTO ${ }^{3 *}$
}

A total of 82 cases of breast cancer detected by hand-scanning ultrasound massscreenig (hereafter referred to as US screening) over the past 15 years were divided into two groups - -one aged under 50 and the other aged 50 or over at the time of examinaton. The accuracy and capacity of US screening and the rate of patients with subjective symptoms were studied for each group. As a result, we discovered that the group aged under 50 was significantly higher in the rate of "further examination needed", and the rate of "having subjective symptoms", and was significantly lower in "positive predictivevalue" than the older age group. In the detection rate, sensitivity and specificity, there was no difference between the two groups. Thus, we concluded that US screening were beneficial to both groups.

On pathological investigation, it was found that the rate of non-invasive breast cancer in the group aged under 50 was significantly higher than in the older age group. The result suggested that US screening could detect breast cancer in its early stages before growing to invasive breast cancer in the younger age group.

Dividing the 15 years of US screening into three periods (each 5 years), we investigated the caliber of detected breast cancers, and found the tumor size became smaller year after year. As a result, the cases of non-palpable breast cancer came to form $26.6 \%$, of which $72.3 \%$ was accounted for by invasive breast cancer. Further more, we found that in the group aged under 50 , because of stiffness of their breast gland, the ratio of non-palpable breast cancer came to $30.2 \%$, which was larger than in the older age group, and $69.2 \%$ cases out of them were invasive breast cancer. We are afraid that mass-screening by physical examination alone will overlook many cases of breast cancer, and we recommend that in view of the increasing mortality rate of breast cancer in women in their50s the safe and useful US screening program should be implemented without delay on the younger age group.

${ }^{*}$ Dept. of Surgery, ${ }^{2 *}$ Dept. of Pathology, ${ }^{3 *}$ Dept. of Laboratory Medicine, Ibi General Hospital, Gifu, Japan 